\title{
Waters Transfer Laws and its Discrepancies, a Brief Overview in Some Neighbouring Countries, Including Discussion on Malaysia-Singapore
}

\author{
ROZLINDA MOHAMED FADZIL \\ HANIFF AHAMAT \\ RASYIKAH MD. KHALID
}

\begin{abstract}
A brief overview of a few neighbouring countries which have different legal regimes in water laws and conflicts. There were water transfer conflicting rules in some countries as against water as a right. The clash between environmental are human rights, constrains of market perspective are also discussed. The first part discussed about the codification of water laws as a right or privilege and products containing water, such as agricultural produce are subjected to trade disciplines and trade barriers. In the case of bulk transfers of fresh water, private contractual remedies and negotiations between the parties or remedies available in public international law were reviewed, rather than the remedies provided for in trade agreements disputes such as in NAFTA. The latter part discussed about GATS and remedies in public international laws pertaining to water ownership and water transfer laws.
\end{abstract}

Keywords: Bulk water transfer; GATS; Malaysia-Singapore; NAFTA; water trade; water transfer; WTO

\section{INTRODUCTION}

Fresh water is vital to human life and to the sustainability of Earth. There is no known substitute for fresh water. People have strong emotional ties to water, whether for health, nature, soil productivity, religious, or other reasons. Historically water has not had a price, only the costs of extracting, using, or purifying it. But within the last half of the twentieth century, water increasingly acquired a price, entered into the market, and was subject to international trade. These developments have raised the question of the extent to which international trading regimes apply to transboundary fresh water transfers.

To encourage more efficient use of water and meet water needs, various entities, from cities to agricultural users, are buying and selling water. The market takes the form of often large-scale transfers of specific quantities of water not only within countries (or within a state or province), but also in some cases, between countries. The conflicting trends reflect differences within the international community about how water should be viewed. Some argue that fresh water is a commodity, which ought to have a price, and that the price ought to be high enough to ensure that water is used efficiently. ${ }^{1}$ This is even more important where fresh water is scarce and the demands many. Others view fresh water as a public good, or as the common heritage of humankind. They point to the essential role of water in ecosystems and to a basic human right to water. ${ }^{2}$ This, they argue, counters or constrains the market perspective. The seeming clash between environmental and human rights concerns which mostly are centered towards drinking water and the trade disciplines which bear analysis.

This paper addresses the extent to which the trade disciplines apply to transboundary movements of fresh water. It does so primarily by examining the 1994 General Agreement on Tariffs and Trade (GATT 1994) ${ }^{3}$ and, secondarily, relevant experience with the North American Free Trade Agreement (NAFTA). ${ }^{4}$ It concludes that while the trade disciplines may conceptually apply at the point where water is removed from its natural state, they should in practice generally be applied only after fresh water has been removed from its bulk status and transformed into traditional products, such as bottled water and other drinks, which are already subject to the trade disciplines. Products containing water, such as agricultural produce, are also already subject to trade disciplines. In the case of bulk transfers of fresh water, private 
contractual remedies negotiated between the parties or remedies available in public international law, rather than remedies provided for in trade agreements, should be used to address disputes.

\section{THE CHARACTERISTICS OF FRESH WATER}

Fresh water is a unique resource, because all forms of life need it, and there are no known substitutes. The actions we take today influence the amount and quality of fresh water available in the future. Human-induced climate change affects the amount and distribution of precipitation, and hence the quantity of water available in watercourses and rechargeable aquifers. $^{5}$

Water is oblivious to national boundaries. Countries share international rivers, lakes, and sometimes ground water aquifers. The hydrological system for any given water basin may reside in more than one country. This means that actions by one country in a river basin, even on a distant tributary, may influence the quantity and quality of water available to another country in the river basin.

The characteristics of fresh water differentiate fresh water from other tradable natural resources such as timber, fish, or fossil fuels. Our dependency on fresh water now and in the future must condition the application of international trade law to this essential resource.

\section{TRANSBOUNDARY TRANSFERS OF WATER}

Water crosses national boundaries in at least three different forms by natural or artificial flows in rivers, streams, or aquifers; by bulk transfers, which require the removal of water into pipelines, tankers or other conveyance vehicles; and by incorporation into products, whether as drinking water, agricultural produce or other items. ${ }^{6}$ The first form should not, and does not, invoke trade disciplines, while the last clearly does. The legal treatment of bulk transfers of water across national borders has yet to be resolved.

\section{EXPORT OF BULK WATER}

Bulk transfers of fresh water raise the most difficult issues for the application of trade agreements. Bulk water removal may be defined as removal by human-made diversions, including canals, tanker ships, trucks, or pipeline. ${ }^{7}$ Governments may transfer from one State to another; private parties in different States may contract for the transfers. The transaction could involve a government exporter and a private importer, or even a private exporter and a government importer. The relations between the parties are contractual in nature, and even if executed by governments, may not take the form of treaties. This category of transfer raises the most difficult issues, because it clearly pits environmental and ecological concerns against free trade concerns. These issues are addressed in detail below. The paper concludes that while technically these bulk transfers may constitute goods in trade, the precautionary approach in international law as developed and applied to fresh water makes it important to exclude them from the reach of trade law, as least for now until more experience is gained with them. Were this position adopted, bulk transfers for a specified purpose, i.e. for hydroelectric power, could be excluded from this general exclusion if necessary. ${ }^{8}$

\section{WATER AS A GOOD OR PRODUCT}

At what point does water become a good or a product subject to the WTO/GATT 1994? ${ }^{9}$ If water is a good subject to the GATT 1994, it will be considered a good subject to the NAFTA. The NAFTA defines a 'good' subject to its provisions as 'domestic products as these are understood in the General Agreement on Tariffs and Trade'. ${ }^{10}$ The GATT 1994 contains no definition of 'good' or 'product'. However, the World Customs Union's Harmonizing Commodity Description and Coding System, which identifies products for tariffs purposes under the GATT 1994, covers water in various forms. ${ }^{11}$ Heading 22.01 includes 'waters, including natural or artificial mineral and aerated waters, not containing added sugar or other sweetening matter nor flavored; ice and snow'. ${ }^{12}$ An explanatory note adds 'ordinary water of all kinds (other than sea water)'. The subheadings cover Mineral waters and aerated waters' and 'Other'. ${ }^{13}$ While it may seem odd to include 'ice', in the nineteenth century the sale of ice was a major enterprise in the northeastern part of the United States. ${ }^{14}$ Heading 
22.02 covers 'Waters, including mineral waters and aerated waters, containing added sugar or other sweetening matter or flavored and other nonalcoholic beverages, not including fruit or vegetable juices of Heading 20.09..$^{5}$ Heading 25.01 covers 'salt (including table salt and denatured salt) ... ; sea water'. ${ }^{16}$ The Canadian Department of Foreign Affairs and International Trade notes that because Canada's (and most other countries') tariff schedule includes 'natural waters' as a tariff heading, some commentators have suggested that this means that all water must be considered as a good. But the Department concludes: 'This is a mistaken view of the purpose of the tariff schedule. . . it does not tell us if and when water is a good; it only tells us that when water is classified as a good, it falls under a particular tariff heading. ${ }^{17}$

From this classification of goods for tariff purposes, nonetheless, some might argue that the GATT 1994 covers any diversion of water from its natural state, whether from the surface or by extension from an aquifer. This could extend to all diversions of water or pumping of water for any purpose, since the water would be removed from its natural state. Should the diversion or pumping cross national borders, it would be subject to the trade disciplines.

The broad interpretation of the definition of 'good' and of 'product' to cover water in its natural state is arguably inconsistent with the intent and the language of the GATT 1994 regarding tariffs. In any case, it is unwise. The description for purposes of the Harmonized Tariff Schedule refers to water when it has entered into trade as a commodity. It is doubtful that the authors of the Tariff Schedule contemplated covering, or intended to cover, water in its natural state or large-scale bulk transfers of water. There is no tariff binding yet on water. Moreover, it is not clear that any State has established a schedule for water. In October 2001, Mexico circulated a Notification to the Committee on Technical Barriers to Trade ('TBT') of its draft Mexican Official Standard regarding sanitary specifications for water and ice for human consumption, 'either pre-packaged or in bulk, except for water consumed directly from supply systems'. ${ }^{18}$ However, a Notification under the Technical Barriers to Trade Agreement of the WTO is completely separate from the Tariff Schedule. It does suggest, though, that at the point when bulk water becomes subject to human consumption, such as for drinking water, it becomes a good or product for purposes of the TBT.

The GATT 1994 does not expressly define the term 'product'. According to the Oxford Compact English Dictionary, 'product' originates from the Latin word meaning 'something produced', and can be defined as 'a substance produced during a natural, chemical, or manufacturing process. $^{19}$ This suggests that something must be done to water to make it a product, and that mere diversion, pumping, or transfer does not suffice. As long as it remains in its natural state or source, water could not be a 'product'. Water is mobile, it seeps into the ground, evaporates into the air, flows in sometimes unpredictable ways, 'dries up' or inundates land areas. When it is maintained as in stream flow (as for recreational, fisheries, or tourist uses), or diverted or transferred in earthen canals, similar physical processes take place, which makes it difficult to characterize it as a product.

Canada, Mexico and the United States addressed the issue of fresh water in relation to the NAFTA. In 1993, the three governments issued the following statement regarding the application of the NAFTA to water:

The NAFTA creates no rights to the natural water resources of any Party to the Agreement.

Unless water, in any form, has entered into commerce and become a good or product, it is not covered by the provisions of any trade agreement including the NAFTA. And nothing in the NAFTA would oblige any NAFTA Party to either exploit its water for commercial use, or to begin exporting water in any form. Water in its natural state in lakes, rivers, reservoirs, aquifers, water basins and the like is not a good or product, is not traded, and therefore is not and never has been subject to the terms of any trade agreement. ${ }^{20}$

The U.S. Deputy Trade Representative reaffirmed this position in a 1999 letter to the International Joint Commission in connection with the Commission's deliberations on diversion of water from the Great Lakes. The letter noted that '.. the WTO simply has nothing to say regarding the basic decision by governments on whether to permit the 
extraction of water from lakes and rivers in their territory,' although it did observe that ' $[\mathrm{t}]$ his is not say that WTO rules could never apply to water which has been extracted from a watercourse and actually traded in international commerce. $^{21}$ The Canadian Department of Foreign Affairs and International Trade was equally explicit:

Water in its natural state can be equated with other natural resources, such as trees in the forest, fish in the sea, or minerals in the ground. While all of these things can be transformed into saleable commodities through harvesting or extraction, until that crucial step is taken they remain natural resources and outside the scope of the trade agreements. $^{22}$

In its 2000 report on 'Protection of the Waters of the Great Lakes', the International Joint Commission between Canada and the United States reaffirmed the governmental positions that water in its natural state is not a good. But the Commission noted that '[w]hen water is "captured" and enters into commerce, it may, however, attract obligations under the GATT, the FTA, and the NAFTA' ${ }^{23}$

The question remains: at what point is water deemed to be captured and to enter into commerce? Are bulk transfers across national borders included? Should they be?

\section{THE RELEVANCE OF THE GATT 1994 TO BULK TRANSFERS}

International agreements specific to particular international river basins may provide rules of allocation and use that determine whether transfers in bulk of fresh water from the river basin are legal. Alternatively, there may be no relevant international water agreements; only national, provincial, or local laws may govern the legality of the transfer. In the absence of legal constraints, such transfers would be permitted. International trade law comes on top of this existing framework of regulation.

\section{THE APPLICABLE TRADE PROVISIONS}

Three articles of the GATT 1994 contain the provisions most readily applicable to transboundary water transfers: Articles I, III, and XI. Of these the last is likely the most relevant.

Article XI(1) provides the substantive rule on export and import restrictions:
No prohibitions or restrictions other than duties, taxes or other charges ... shall be instituted ... on the importation of any product ... or on the exportation or sale for export of any product destined for the territory of any other contracting party. ${ }^{24}$

Article $\mathrm{XI}(2)$ (a) provides an exception to this general prohibition for 'export prohibitions or restrictions temporarily applied to prevent or relieve critical shortages of food stuffs or other products essential to the exporting contracting party'. ${ }^{25}$

Whether Article XI applies depends initially on whether a bulk transfer of fresh water is considered a product. If it is not, Article XI does not apply. If it is a product, then a State's ban on the export (or import) of fresh water would violate Article XI, unless it were covered by the exception in Article XI(2) or other general exception under Article XX. In certain cases, such as drought, unexpected contamination of water supplies as by accidents or natural disasters, or other such emergencies, temporary restrictions on exports could be justified under the exception. The shortage would need to be critical and essential to the exporting country, but presumably, in certain emergencies, fresh water would qualify. However, the export restrictions could only be temporary. The exception would not be available to support restraints on the export of fresh water when water shortages were not critical.

Countries may want to restrict exports not only to provide fresh water to people and to their industries, but also to protect ecology and river basin ecosystems. Fish and other wildlife and flora depend upon fresh water resources. If fresh water were to be viewed as a product even in its natural state, and the river basin ecosystem as essential to the country, then the exception in Article XI(2) might become relevant should the ecosystem be threatened.

Article III provides for national treatment of international taxation and regulations for both domestic and imported products. Article III(4) provides that the imported products 'shall be accorded treatment no less favourable than that accorded to like products of national origin in respect of all laws, regulations and requirements affecting their internal sale, offering for sale, purchase, transportation, distribution or use'. ${ }^{26}$ If bulk transfers of water were to be treated as 'like products', the requirements of 
national treatment would apply. Issues might arise in the context of regulations over the quality of imported water, but it is not clear why countries would want to regulate the quality of water transfers domestically, as treatment of water for a given quality is generally considered as a separate issue.

Article I might also be relevant to bulk transfers. Article I provides for general most favoured nation treatment, which requires that any of the specified categories of 'favours' granted by one country to any product originating in or destined for any other country be accorded 'immediately and unconditionally to the like product originating in or destined for the territories of all other contracting parties'. ${ }^{27}$ Were the GATT 1994 to apply to bulk transfers, and were a country to receive bulk water transfers from more than one country or export such water to more than one country, the disciplines of Article I could restrain countries from discriminating among 'receivers or senders' in the favors granted.

If a country were to violate Articles XI, III, or I, then the exceptions in Article $\mathrm{XX}(\mathrm{b})$ and (g) become relevant. Article XX provides as follows:

Subject to the requirement that such measures are not applied in a manner which would constitute a means of arbitrary or unjustifiable discrimination between countries where the same conditions prevail, or a disguised restriction on international trade, nothing in this Agreement shall be construed to prevent the adoption or enforcement by any contracting party of measures:

(b) necessary to protect human, animal or plant life or health; (g) relating to the conservation of exhaustible natural resources if such measures are made effective in conjunction with restriction on domestic production or consumption.

According to the WTO Appellate Body in the Reformulated Gasoline $\mathrm{Case}^{28}$ and to practice, the first test is whether one of the exceptions in Article XX applies, and if it does, the next test is whether the chapeau language of Article XX is satisfied.

Prohibitions or restraints on water exports could qualify under the Article XX(b) exception if they were in fact 'necessary to protect human, animal or plant life or health'. This would presumably cover measures necessary to reserve water for the robustness of ecosystems, animal populations, and drinking water and sanitation supplies. One might conceivably argue that it should extend to agriculture on the grounds that agriculture produces food essential to human and animal health, though this argument has not been made. Much of agriculture is destined for export. The Article XX exception presumably would not reach measures that are intended to restrain bulk transfers of water to ensure sufficient supplies for agriculture.

Article $\mathrm{XX}(\mathrm{g})$ provides an exception for measures that relate to the conservation of exhaustible natural resources, but only if such measures are made effective in conjunction with restrictions on domestic production or consumption. Technically fresh water is not an exhaustible natural resource, unless it is contained in fossil ground water aquifers. It merely changes form. However, in any particular location, fresh water can be an exhaustible natural resource in the sense that a decrease in supply may result in essentially irreversible ecological changes. If oil and natural gas are considered exhaustible natural resources, fresh water supplies also should be. A restraint on exports, however, satisfies the paragraph (g) exception only if it is made in conjunction with domestic production or consumption. Prohibitions on exports designed to protect ecosystems might then need to be accompanied by bans on shipments of water out-of-basin. There is precedence for this domestically in the United States, where the Supreme Court has prohibited restraints on the export of ground water between states as violations of the Constitution's Commerce Clause, unless the restrictions are part of a state's own conservation plan which limits use within the state. ${ }^{29}$

Assuming that the measures came either within (b) or (g), they must still satisfy the conditions in the chapeau language,,$^{30}$ namely that the measure not "constitute a means of arbitrary or unjustifiable discrimination between countries where the same conditions prevail, or a disguised restriction on international trade'. Interpreting whether a given measure is 'arbitrary or unjustifiable,' assumes an ability to 'second guess' the country on the need for water supplies to protect the ecosystem now and into the future.

The discussion below examines the several different types of bulk transfer arrangements between countries, and highlights the efforts of some countries to control such exports. The 
subsequent section explores the pros and cons of applying or not applying the GATT 1994 to these transfers.

\section{THE BULK WATER TRANSFER ARRANGEMENTS}

Bulk transfers of water occur between different kinds of actors and in different modes. The most traditional is between governments in the form of treaties. But governments may also enter into contractual arrangements for the export and sale of bulk water. In some cases, the export arrangements are between a government (or its agency) and private companies in another country, or between private parties in both the exporting and importing country. The identity of the actors affects the relevance of the trade law disciplines.

The mode of transfer also differs. Sometimes the water is shipped in bulk in ocean tankers; at other times it is conveyed by pipeline, or conceivably other conveyances. In some cases, it would be possible to convey it by artificial canal or similar earthen mechanism. The mode of transfer should not, however, affect the application of the trade law disciplines.

\section{Government to government transfers by treaty}

Sometimes large-scale transfers of water take place pursuant to a treaty. For example, the water-rich Kingdom of Lesotho sells water by treaty to the Republic of South Africa. In return for providing a reliable source of water, the South African government guarantees millions of dollars in payment to Lesotho. $^{31}$ The recently completed $\$ 2.5$ billion Katse Dam, which is the first phase of the Highlands Water Project, catches water from Lesotho's highlands and ferries it via an elaborate system of dams and underground tunnels to South Africa. ${ }^{32}$ The project transfers about 910 cubic feet of water per second from Lesotho to six of South Africa's nine provinces. The treaty between the two countries created several entities that are charged with jointly implementing the project. The project, which is partially funded by the World Bank, is a prototype for other water resource development projects.
The Kingdom of Lesotho is under no obligation to reach agreement with other neighboring countries to provide fresh water. Lesotho could also decide not to comply with its obligation to provide the water, and the remedies would be those available under the treaty, with the funding entity, or generally in public international law.

One could argue that water is certainly a good here, that it has a price, and that the receiving country would suffer should Lesotho decide to ban the export of water from Lesotho. Moreover, neighboring countries, such as Mozambique, are not happy about the water exports going to South Africa. While all of this may be true, there is still no obligation in trade law for a country to sell its water outside its border nor should trade disciplines affect the choice of importer. Moreover, in this case, under the rules of the Vienna Convention on Treaties, the treaty between the two countries should prevail.

2. Government to government contractual transfers

Israel and Turkey have signed a ten-year contractual agreement in which Israel is to buy 50 million cubic meters of water annually from the Manavgat region of Turkey. The agreement is for twenty years. The water will be shipped in bulk by sea to Israel. A spokesman for the Israel Foreign Ministry said that the agreement was a landmark, which turns water into an internationally accepted 'commodity'.

Other water exports between countries are taking place between Turkey, Malta, Cyprus, and the Gulf countries, where fresh water is very scarce. A thirty-year contract between Iran and Kuwait; and between neighbouring Qatar and Saudi Arabia. In Southeast Asia, Malaysia sends untreated water to Singapore, which treats it and sells some of it back to Malaysia for a profit.

3. Transfers between government and foreign private party

The transfers between countries may also take place between the national government (or a branch of it) and foreign companies. For 
example, Bolivia permits the export of water by the government to foreign users. In November 2001, the Bolivian Parliament approved its Water Export Law, which permits the Bolivian Water Resources Corporation (COBOREH) to export water. The immediate export project is to mining companies in Chile. Plans called for initial export of 800 liters per second, rising to 3,000 liters per second at the end of the project's third year.

\section{NATIONAL AND LOCAL EFFORTS TO LIMIT EXPORTS OF WATER}

At the same time that some countries, such as Bolivia or Turkey, are initiating exports of bulk water, other countries are limiting exports of water, both at the national and provincial or local levels. Canada provides an excellent example of limitations on bulk water export at both the federal and provincial level. The Canadian Constitution makes it clear that many water issues, including flow regulation, authorization of water use development, and the authority to legislate in areas of water supply, pollution control, and thermal/hydroelectric power development, remain under provincial control. However, a federal water policy also exists. The federal policy seeks to implement a strategy of cooperation with provincial governments on water management issues and dictates that all possible measures will be taken to prohibit the export of water from Canada through inter-basin transfers. Canada also amended the International Boundary Waters Treaty Act in 2001 to prohibit removing boundary waters outside the water basin.

The locus of authority for water resources at the provincial level has important implications for implementation of the GATT 1994. If only a country's subnational units attempted to limit international exports of water from their borders, any of the GATT 1994 obligations discussed above that could apply to prevent such restraints might not be enforceable beyond the country's federal government. Specifically, because the GATT 1994 in Article XXIV(12) requires a contracting party to take 'reasonable measures ... to ensure observance of the provisions of this Agreement ... within its territory', a national government might not breach its GATT 1994 obligations as long as it does 'everything within its power' to win compliance from its states or provinces, regardless of whether or not it succeeds.

\section{EVALUATING THE APPLICATION OF WTO/GATT 1994 TO BULK TRANSFERS}

Whether the GATT 1994 applies to bulk transfers of water has important policy implications for international trade, water and agricultural policy, and ecosystem protection. This paper examines both the reasons to apply the GATT 1994 and those reasons which caution against doing so.

\section{REASONS TO APPLY THE GATT 1994}

The reasons for extending the application of the GATT 1994 to fresh water resources relate to water's economic value and to the need to reduce barriers to trade among States. Several reasons are discussed below.

1. Recognizes the status of water as a commodity

When fresh water is transferred in bulk across a national boundary, it is generally for the purpose either of turning it into products, such as bottled water or other drink, or of using it to produce products, including agricultural produce. In theory it could also be transported for the purpose of generating electricity. Conceivably it could also be done to protect tourist areas, natural habitats, or ecosystems that have been threatened by drought. Except for the last, all of the above uses mean that bulk water is being exported and imported because of its value as an economic good. This argues for treating bulk transfers as other articles of commerce, i.e. for subjecting them to the trade disciplines. In the absence of a compelling reason to the contrary, water should not be treated differently.

2. Levels the playing field for trade in water resources

If bulk water is subject to the trade disciplines, exporters in one country cannot favor one importing country over another. Similarly, importers cannot discriminate in favor of water from one country over that 
from another by imposing differential tariffs or quantitative limitations. This would in theory protect against bulk water being used to gain a competitive advantage. However, in many, if not most, countries water does not by itself have an economic price. The cost of bulk transfers will vary markedly depending upon mode and cost of transport and ease of extraction, i.e. it may be arbitrary and not a good guide to comparative advantage.

\section{Protects against disguised barriers to trade}

Limitations, or outright bans, on the export of water across national boundaries, or even bans on transferring water out of a river basin within countries, raise the possibility that such actions are intended to protect domestic water supply for economic reasons rather than to protect the ecosystem, or for some other environmental or health reason. Export restraints may be imposed in order to hold onto water so that it can be used for agriculture, thus arguably subsidizing agriculture and ensuring cheaper produce for markets. The export controls may be justified as protecting the productivity of the land. It may be difficult to determine when they are required for protecting the environmental integrity of an area, and when they provide cheap agricultural subsidies and constitute a disguised barrier to competitive trade. All of the above considerations support subjecting bulk transfers of fresh water, at least initially, to the trade disciplines.

\section{REASONS NOT TO APPLY THE GATT 1994 TO WATER IN ITS NATURAL STATE OR TO BULK TRANSFERS}

The reasons against applying the GATT 1994 focus on the affront to a country in exercising its national sovereignty to allocate, use, and protect its fresh water resources, and on the need for an anticipatory cautionary approach in addressing water issues.

1. Constrains a State's ability to protect ecological systems
Fresh water is essential for satisfying human needs and for protecting ecosystems and river ecology. One of the functions of governments is to be able to ensure that sufficient water is available to protect the integrity and diversity of ecosystems. Weather and climate, coupled with land use practices, largely determine how much fresh water is naturally available in any given season within a river basin. While dams and reservoirs affect quantities made available for specific uses, the underlying natural phenomena may yield marked variations over time in precipitation and ground water recharge. Governments need to be able to impose restrictions in times of scarcity to ensure that sufficient water is available to meet basic needs and to protect ecosystems.

If bulk transfers are subject to the trade disciplines, it will make it more difficult to take the measures required to meet basic needs and protect ecosystems. While the exception in Article $\mathrm{XI}(2)(\mathrm{a})$ might be available, the trade community would determine whether the measures qualified for the exception. If such measures are not subject to the trade disciplines, States could restrict the transfer of water resources more freely. Whether the importer, or the private investor in a State's water resources must be compensated is then a matter of domestic legislation.

2. Makes long-term management of water resources more difficult

It is inherently difficult to predict adequately the long-term demand for and supply-of water resources. This is particularly so in the face of climate change. This makes long-term management of water resources inherently difficult. While the water resources may be sufficient at one time to satisfy economic needs and protect ecosystems, they may not be in the future. When greater need for the water arises, out-of-basin diversions or contracts for the export of water may be difficult to suspend or cancel. Yet continuing to export water could stunt economic growth at home, or, worse, lead to arid, unproductive lands that lack water. 
States or provinces may want to limit the export of fresh water to other countries because it is difficult to calculate future demand for the water. Once the water importer has a right, prior appropriation takes effect in practice against the subsequent need. Canceling the contract-or agreement can be costly. These situations exist today. However, they would be made much more difficult if bulk transfers, or transfers of fresh water in its natural state, were subject to the trade disciplines. This is because such decisions would be subject to the additional scrutiny of whether they could be regarded as distortions of trade in violation of the GATT 1994. Governments need to be able to exercise caution with regard to exporting (and importing) water resources, without the trade community deciding whether there is sufficient scientific evidence to justify the trade restriction.

3. Gives trade considerations a significant voice in reconciling conflicting uses of water.

If bulk transfers, or natural flow transfers, were subject to the trade disciplines, it would mean that within countries, those public officials charged with implementing the trade agreements would have a voice in determining whether actions affecting the allocation and use of water resources could be taken. This would have important negative effects.

It could make it more difficult to take the necessary actions to protect ecosystems in times of emergencies, or especially in times when shortages are forecast on the basis of hydrological and meteorological data. Trade considerations could delay decision-making and make the deliberations more complex. If bulk transfers were subject to the GATT 1994, those public officials responsible for complying with international trade agreements would have an important voice in determining whether actions nationally or locally to protect water resources could be taken. The national agency responsible for trade would be empowered in relation to those concerned with water resources in ways that do not exist today.

In countries where provincial governments hold the primary authority for decisions regarding water resources, such as Canada, national concerns about trade agreements could engender national-provincial conflicts. A provincial government might want to ban transfers in a manner that the trade ministry would regard as contravening the trade agreements. Under one scenario, conservation interests would need to push their interests at the national level, and the national government might not be willing to support the provincial government (for political reasons or otherwise). The environment or natural resources ministry might press for water conservation, but lack power to do so against pressures from the trade ministry to the contrary.

4. Gives trade dispute settlement mechanisms authority to resolve water claims.

If bulk transfers, or natural flow transfers, were subject to the trade disciplines, the dispute resolution mechanisms set up under the trade agreements would be available to resolve disputes over such transfers. This could mean that the same disputes could come before different bodies, depending upon whether they arose under a multilateral or bilateral water treaty, or only under a trade agreement. Disputes that arose under international water agreements would be subject to the dispute resolution mechanisms provided in the treaty, under public international law, in domestic courts, or in other forums of dispute resolution, while other disputes involving similar transfers could go before the trade dispute settlement bodies. This could encourage forum shopping and result in very different decisions for similar disputes. Moreover, it would mean that disputes about the allocation and use of water, and about the legitimacy of measures to protect ecosystems and river ecology, 
could be made by trade bodies. The latter lack the requisite expertise to decide such disputes and would be inappropriate method.

\section{STRIKING THE BALANCE}

Developing countries, especially the least developed countries, or middle-income countries with abundant water resources, may find the export of fresh water attractive, for they earn revenue from it. Moreover, since water stimulates development, they may view efforts of developed countries to prevent the export of water as unfair on their part, since they have already achieved development. These arguments could be, and have been, raised in many international environmental issues.

In striking the balance for fresh water, it is essential to consider that water is different from other natural resources. It is a unique resource. Fresh water is essential for human life and for ecosystems, and there are no known substitutes for water. Moreover, people have strong emotional ties to water. Thus, it would be prudent to adopt an approach of 'anticipatory caution', to strike the appropriate balance between the need to conserve water resources and the need to ensure a level playing field in trading relationships. Anticipatory caution means that in the face of uncertainty about the future, a country should be able to exercise its sovereign authority to maintain its fresh water resources without having to convince the trade community of the legitimacy of its actions. This is especially important because of the difficulty of predicting water demand and water supply, and of anticipating adequately the natural variations that will affect water availability and the stability and integrity of the Earth's ecosystems. Anticipatory caution is an extension of, or complement to, the precautionary approach, which is well reflected in international law. It is especially relevant to the management of fresh water resources.

Exempting bulk transfers together with water in its natural state from trade agreements would be consistent with the de facto status of oil resources under the trade agreements. For historical reasons, oil has not been subject to the GATT 1994. This is because many of the countries who are the largest producers of oil were not contracting parties to the GATT 1947, prior to the WTO, and some still are not members of the WTO. Of those countries that each produce more than approximately $2 \%$ of the world's oil, only Brazil, Canada, Indonesia, Kuwait, Nigeria, Norway, the United Kingdom, the United States, and Venezuela were party to the former GATT prior to the WTO. Only four member countries in OPEC were party to the prior GATT, and only $2 / 3$ were members of the WTO/GATT 1994 as of 1st January, 2005. Saudi Arabia, Iran, Iraq, and Algeria, members of OPEC, were not members of the WTO.

While trade in oil would conceptually be subject to the trade disciplines as oil is considered a product in the market place, the failure to subject it to the trade disciplines provides strong precedent for not subjecting bulk transfers of water across national borders to the trade disciplines. Moreover, unlike oil, fresh water is a resource for which there are no known substitutes, and it serves vital functions for both people and the Earth's ecosystems.

\section{MALAYSIA'S JUDICIAL APPLICATION OF INTERNATIONAL LAW - WATER AGREEMENT}

The paper tries to answer the questions in the light of one leading Malaysian unresolved dispute with her neighbour. The paper concludes that although the Malaysian courts apply international treaties as part of the Malaysian law so long as they have been transformed into domestic law by means of an act of Parliament, the application of customary international law by the Malaysian courts is not so consistent and that a clear-cut policy is required to have a consistent and justifiable judicial practice.

It is often said that the doctrines of incorporation and transformation correspond with 'monism' and 'dualism' respectively. It means that according to monism, international law and municipal law are part of the same legal order and this is reflected by the fact that international law is automatically incorporated into municipal law. Conversely, under dualism, international law and municipal law are two separate systems of law operating in its own area of competence. This is the same thing as saying that rules of international law can operate in a national legal 
system only if they are deliberately transformed into it by means of a parliamentary enactment.

\section{APPLICATION OF INTERNATIONAL TREATIES}

The Federal Constitution of Malaysia, unlike the constitutions of some other States, does not contain any provision which says that international law shall be deemed part of the law of the land or that treaties shall be the laws of Malaysia. Nevertheless, certain provisions of the Constitution deal with 'treaty-making capacity' in Malaysia.

This has been reaffirmed by the case of the Government of the State of Kelantan $\mathrm{v}$ the Government of the Federation of Malaya and Tunku Abdul Rahman Putra Al-Haj [1963] 1 LNS 145 HC. In this case, Kelantan challenged the constitutionality of the Malaysia Agreement, which was an international treaty signed by the United Kingdom, the Federation of Malaya, Singapore, Sabah and Sarawak. The main argument made by the Kelantan Government was that the consent of the individual States of the Federation of Malaya should have been obtained before the arrangements for Malaysia can be lawfully implemented. Referring to Articles 39 and 80 (1) of the Federal Constitution, the Court affirms the constitutionality of the Malaysia Agreement as follows:

The Malaysia Agreement is signed 'for the Federation of Malaya' by the Prime Minister, the Deputy Prime Minister and four other members of the Cabinet. There is nothing whatsoever in the Constitution requiring consultation with any State Government or the Ruler of any State.

The conclusion then is that as far as treaties are concerned, the Malaysian practice is based on the 'doctrine of transformation'. Even though the Government (Executive) has ratified a treaty and the treaty binds the Government under international law, it has no legal effect domestically unless the Legislature passes a law to give legal effect to that treaty. The following are a few examples of statutes made by Parliament to give legal effect to treaties concluded by Malaysia:

a. The Geneva Conventions Act, 1962, as revised in 1993, to give legal effect to the
Four Geneva Conventions for the Protection of the Victims of War of 1949;

b. The Diplomatic Privileges (Vienna Convention) Act 1966, as amended in 1999, to give legal effect to the Vienna Convention on Diplomatic Relations 1961;

c. The Carriage by Air Act, 1974, to give legal effect to the Warsaw Convention of 1929, as amended by the Hague Protocol of 1955 and the Guadalajara Convention of 1961;

d. The Exclusive Economic Zone Act, 1984, to give legal effect to certain provisions of the United Nations Convention on the Law of the Sea 1982.

e. The International Organisations (Privileges and Immunities) Act 1992, to give legal effect to the Convention on the Privileges and Immunities of the United Nations 1946.

f. The Consular Relations (Privileges and Immunities) Act 1999, to give legal effect to the Vienna Convention on Consular Relations 1963

\section{THE STORY OF MALAYSIA AND SINGAPORE}

Since the bloody race riots of the 1960s that led to the separation of Singapore and Malaysia, numerous avenues were developed to instigate the peaceful settlement of disputes, in the realm of public international law. Whilst current bilateral relationships between the two countries are at peace, it is hoped that the situation will continue for a long time in the future. Being neighbours, however there are bound to be problems, the most highly publicised one of all, water.

In preventing future violence from erupting, not only for water and the problems it brings to Malaysia and Singapore but also to other future disputes on other matters, to both countries this paper will look at all the available avenues to a peaceful settlement of dispute. There are many dispute settlement mechanisms available, for the purposes of this paper due to human imperfections i.e. time, geographical and monetary constrains, this paper will concentrate on three dispute settlement mechanism.

The first is the International Court of Justice (ICJ), the second, the World Trade Organisation's (WTO) Dispute Settlement Body (DSB) and lastly, the International Centre for the Settlement of Investment Dispute (ICSID). 


\section{HISTORICAL BACKGROUND 47}

Malaya (now peninsular Malaysia) and the Straits Settlements, with Singapore as its hub, were under coordinated British colonial rule from the early nineteenth century until Malaya became independent in 1957 and Singapore in 1965. In 1963, Singapore joined Malaya and two Borneo states to form Malaysia. It was a turbulent union between the governing Malay majority of Malaysia and the primarily Chinese population of Singapore, and in 1965, after two race riots, Kuala Lumpur expelled Singapore from Malaysia.

Two vital water agreements, signed in 1961 and 1962, were confirmed and guaranteed in the 1965 Separation Agreement. Singapore built and maintains the waterworks in a state in Malaysia, Johor (dams, pipelines, reservoirs) and has 'the sole and absolute right' to a fixed amount of raw water until 2011 and 2061, respectively. The price of this water is very low, three Malaysian cents per 1,000 gallons (currently, one British pence equals five Malaysia cents), and the treated water that Singapore is obligated to sell back to Johor is well below cost.

In looking at how the modes that water services in the Malaysia and Singapore dispute can be resolved, two other dispute settlement mechanisms (DSM), the International Courts of Justice (ICJ) under the auspices of the Charter of the United Nations and International Centre for the Settlement of Disputes (ICSID) established under the Washington Convention in 1966, are compared together with the WTO. In comparing outcomes of procedural law when the dispute is triggered under the provisions of different DSMs with different jurisdiction and provisions, the best regime of law that encapsulates the best interest of both the peoples of Malaysia and Singapore is bound to be found.

In order to seek out the very best possible settlement with the decision being capable of enforcement with any party not adhering to the decision sanctioned, we shall be looking at comparing the Dispute Settlement Mechanism (DSM) at:

a. The International Courts of Justice (ICJ)

b. The World Trade Organisation (WTO)

c. International Centre for the Settlement Of Disputes (ICSID)
In order to gauge which DSM is the best, we shall be inserting the water problem faced by Malaysia and Singapore which has yet to be solved into the equation of the procedural rules of law provided by the three DSM machinery for enforcing those rights and duties by looking at the yardstick which is water services supply between two countries albeit using concessionaires or the countries itself as parties.

Each circumstance and state of affairs will be examined to determine whether such parties have a right to resort to the three DSMs in the list. Moreover, by looking at a measure of like cases and case law of each of the three DSM, a determination of which DSM is the best one to resort to is seen, not forgetting to look at what happens to a case post decision at the DSM i.e. in the arena of enforcement procedures and penalties of sanctions.

\section{DISCUSSION}

What is the best Dispute Settlement Procedure that Malaysia \& Singapore can resort to in relation to the current water dispute? What is the case laws and how are decisions being adopted? What would be the best possible settlement, solution, best enforcement of decisions, possible sanctions for uncooperative party? Possibly the questions and answers on the further neighbouring conflict with the archaic China's South China Sea claim could also be explored.

We shall evaluate the effectiveness of the three DSM in solving a risen trade dispute, in terms of its rules and procedure by analyzing the strengths and flaws that exist in each DSM, such as:

a. Is there an investment element to the disputes in Singapore and Malaysia, since Singapore built and maintains the waterworks (dams, pipelines, reservoirs) in Johor that would trigger ICSID's involvement?

b. How would the decision in ICSID be adopted and enforced?

c. Was there an infringement of national sovereignty of either Malaysia or Singapore that would quell a valid response to the ICJ?

d. How would the decision in ICJ be adopted and enforced? 
e. Can Malaysia and Singapore utilise the WTO's DSB to settle their problem, under GATS. Can they invoke it? Do they have a right?

f. Can Malaysia and Singapore affect the ICJ's DSM to settle their problem, under UN Charter

g. Can they invoke it? Do they have a right?

h. Can Malaysia and Singapore apply the ICSID's DSM to settle their problem, under the Convention. Can they invoke it? Do they have a right?

i. Whether the service provided by Malaysia in supplying raw water is catergorised as a service under the scope of GATS.

j. Whether the service provided by Singapore in supplying treated water is catergorised as a service under the scope of GATS.

$\mathrm{k}$. Whether the contract is deemed as a concession contract and not government procurement, invoking GATS.

1. The question of true profit or just getting by and actual loss.

m. Is there an investment element to the disputes in Singapore and Malaysia, since Singapore built and maintains the waterworks (dams, pipelines, reservoirs) in Johor that would trigger ICSID's involvement?

n. How would the decision in ICSID be adopted and enforced?

o. Was there an infringement of national sovereignty of either Malaysia or Singapore that would quell a valid response to the ICJ?

p. How would the decision in ICJ be adopted and enforced?

The evaluation will be focused specifically on assessing how well all dispute settlement mechanism (DSM) has worked, and try to answer the question of why there have been 37 violent conflicts between states involving water rights and access to water and to prevent the same fate befall Malaysia and Singapore.

It is vital that the general importance of water is not compromised when it is marketed and sold internationally. Thus it is crucial that there exist a coherent body of law that governs such transactions and a mechanism such as the DSM where parties vested or otherwise can get justice if their rights are infringed.

This further promotes basic and affordable water services that are capable of being able to reach all income levels simply by contributing in the wealth of knowledge that there are available, just regulatory international organisations that are there to provide a check and balance should disputes arise when water is sold beyond borders. This inevitably will improve investment to the water sector increasing trading of water services across borders, giving access to better water services for everyone.

\section{CONCLUSIONS}

The essential role of fresh water in ecosystems and human life requires a cautionary approach in considering the application of the trade disciplines. Bulk transfers of water across national borders raise more difficult issues in determining whether the trade disciplines, and in particular the GATT 1994, apply or should apply. Because water serves vital roles both for human life and for ecosystems, it is important to adopt an approach of anticipatory caution in subjecting bulk transfers of fresh water to international trade rules. It is especially important that the trade disciplines not apply to bulk transfers in such a way that they triumph over the need to ensure that fresh water can continue to serve its essential functions.

Members of the WTO should consider either developing an Interpretation clarifying the application of the WTO to fresh water resources, or a consensus Statement by the Chair of the WTO General Council. Alternatively, concerned countries could issue a clarifying Statement, as the three countries party to the NAFTA did. The Statement accompanied but did not form part of the formal agreement. While that Statement referred to water in its natural state and did not explicitly mention bulk transfers, a Statement concerning the WTO/ GATT 1994 could explicitly cover water in it a natural state and bulk transfers of water. Such actions may be premature, given the fledgling international economy in water and the absence yet of serious international conflicts over water trade, but they could be considered for the future.

The water negotiations and arrangements between Singapore and Malaysia can be re-visited and resolved through:
a. Mediation
b. Arbitration 
c. Dispute Settlement Procedures/ Mechanism.

i. The International Courts of Justice (ICJ)

ii. The World Trade Organisation (WTO)

iii. International Centre for the Settlement of Disputes (ICSID)

Even though the Government (Executive) has ratified a treaty and the treaty binds the Government under international law, it has no legal effect domestically unless the Legislature passes a law to give legal effect to that treaty.

\section{NOTES}

See, e.g., Sharing Scarcity: Gainers And Losers In Water Marketing (Harold O. Carter, et al. eds, 1994); Continental Water Marketing (Terry L. Anderson, ed., 1994); Gary D. Libecap, Rescuing Water Markets: Lessons From Owens Valley, 2005.

2 Salman M. A. Salman \& Siobhan Mclnerney-Lankford, The Human Right To Water, 2004.

3 General Agreement on Tariffs and Trade, April 15, 1994, 1867 U.N.T.S. 3, available at http:// www.wto.org/english/ docs_e/legal_e/ursum_e.htm\#General [hereinafter GATT 1994].

4 North American Free Trade Agreement, December 17 1992, U.S.-Can.-Mex, available at http://www.nafta-secalena.org/DefaultSite/index e.aspx [hereinafter NAFTA].

5 See Intergovernmental Panel on Climate Change (IPCC), Third Assessment Report, Climate Change 2001: Impacts, Adaptation and Vulnerability Ch. 4.3.2 Precipitation (2001), available at http://www.grida.no/climate/ipcc_tar/ wg2/index.htm

6 S. Hodgson, Land And Water-The Rights Interface, See Chapter 6, Food And Agriculture Organization Of The United Nations Rome, 2004, Fao Legislative Study 84.

7 See Canadian Government: Strategy [to] Prohibit the Bulk Removal of Canadian Water, Including Water for Export, M2PRESSWIRE, February 2, 1999, available at 1999 WL 12604553. Removal for bottling would not qualify.

8 Quebec Water Resources Preservation Act, R.S.Q. P-18.1, sec. 2, para. 1 (1999), available at http://www.canlii.org/ qc/laws/sta/p-18.1/20041104/whole.htm.

9 For detailed analysis of alternative approaches in answering this question, see Robert J. Girouard, Water Export Restrictions: A Case Study of WTO Dispute Settlement Strategies and Outcomes, (2003). 247 (15) GEO. INT'L L. REV.

10 See NAFTA, supra note 5, Art. 201, available at http:// www.nafta-sec-alena.org/DefaultSite/index_e.aspx.

11 World Customs Organization, Harmonized Commodity Description And Coding System: Explanatory Notes (3rd edn. 2002).

12 Id. at 186, Heading 22.01 .

13 Id. Explanatory note (A)

14 James M. Utterbach, Mastering The Dynamics Of Innovation 146-157 (1994).

15 World Customs Organization, supra note 24 at 187, Heading 22.02.

16 Id. at 210, Heading 25.01.
17 Bulk Water Removals and International Trade Considerations: Document from the Canadian Department of Foreign Affairs and International Trade, Nov. 16, 1999, International Joint Commission, Protection Of The Waters Of The Great Lakes: Final Report To The Governments Of Canada And The United States, February 22, 2000, p. 67, available at http:// www.ijc.org/php/public ations/ $\mathrm{html} /$ finalreport.html

18 World Trade Organization, Committee on Technical Barriers to Trade, Notification, Doc. G/ TBT/N/Mex/8 (October 3, 2001).

19 Oxford Compact English Dictionary, 2013, available at http://www.askoxford.com/ dictionaries/compact oed/.

201993 Statement by the Governments of Canada, Mexico, and the, United States, available at http://www.scics. gc.ca/cinfo99/83067000_e.html\#statement.

21 Letter from the Deputy United States Trade Representative, November 24, 1999, International Joint Commission, Protection of the Waters of the Great Lakes: Final Report to the Governments of Canada and the United States, February 22, 2000, p. 65, available at http://www.ijc.org/php/publications/html/finalreport.html.

22 Bulk Water Removals and International Trade Considerations: Document from the Canadian Department of Foreign Affairs and International Trade, Nov. 16, 1999, International Joint Commission, Protection of the Waters of the Great Lakes: Final Report to the Governments of Canada and the United States, February 22, 2000, p. 67, available at http:// www. ijc.org/php/ publications/html/finalreport.html.

23 International Joint Commission, Protection Of The Waters Of The Great Lakes: Final Report To The Governments Of Canada And The United States, February 22, 2000, Section 8, Law \& Policy, International Legal Context, available at http://ww.ijc. org/php/publications/html finalreport.html.

24 GATT 1994, supra note 4, Art. X1(1).

25 Id., Art. X1(2) (emphasis added).

26 Id., Art. 111(4)

27 GATT 1994, supra note 4, Art. I.

28 See World Trade Organization Appellate Body: Report of the Appellate Body in the United StatesStandards for Reformulated and Conventional Gasoline (adopted $20^{\text {th May, 1996), W.T.O. Doc. WT/DSZ/AB/R. }}$

29 See Sporhase v. Nebraska, 458 U.S. 941 (1982). A Nebraska statute forbade the transfer of water across state lines without a permit. The Court found that ground water was an article of commerce subject to the Commerce Clause of the United States Constitution, and that the Nebraska statute impermissibly burdened inter-state commerce.

30 For an in-depth discussion of the Art. XX chapeau as it relates to environmental policy and trade, see Sanford Gaines, The WTO's Reading of the GATT Article XX Chapeau: A Disguised Restriction on Environmental Measures, (2001)22 U. PA. J. Int'l Econ. Law 739.

31 Treaty on the Lesotho Highlands Water Project, October 24, 1986, Lesotho-S. Afr., cited in Fred. O. Boadu, Relational Characteristics of Transboundary water Treaties: Lesotho's water Transfer Treaty with the Republic of South Africa, NAT. RESOURCES J. 381 (1998). The treaty has not yet been registered with the United Nations. See also Salman M. A. Salman, Legal Regime for Use and Protection of International 
Watercourses in the Southern African Region: Evolution and Context, (2001). 41 NAT. RESOURCES J. 981 et seq.

32 For more information on the project, see http:// web.worldbank.org/WBSITE/EXTERNAL/ NEWS/0contentMDK:20018028 menuPK:34460 page PK:64003015 piPK:64003012 theSitePK:4607,00.html.

33 See Anderson, supra note 49 at page 243.

34 http://www.circleofblue.org/waternews/2013/world/alaskalegislative-committee-to-discuss-bulk-water-exports/

35 Sun Belt Water, a United States company, issued a notice of intent to sue Canada under Chapter 11 of the NAFTA after British Columbia banned the bulk export of water, for damages over $\$ 200$ million for the loss of a contract to ship Canadian water to California. Sun Belt viewed water as a commodity and British Columbia's ban of bulk exports as providing preferential treatment to Canadian companies in violation of the NAFTA. See Sun Belt Water, Inc. v. Gov't of Canada, November 27, 1998, available at http://www.dfait-maeci.gc.ca/tna-nac/ disp/sunbelt_archive-en.asp.

36 Environment Canada, Water Policy and Legislation: Jurisdictional Responsibilities, at http://www.ec.gc. ca/water/en/policy/coop/e-juris.htm.

37 Canadian Federal Water Policy, available at http://www. ec.gc.ca/water/en/info /pub s/ fedpol/e fedpol.htm

38 An Act to Amend the International Boundary Waters, Treaty, December 18, 2001, 2001. S.C. ch. 40, available at http://www.canlii.org/ca/as/2001/c40/sec1. html.

39 See John H. Jackson et al., Legal Problems Of International Economic Relations 242-4 (4th edn, 2002).

40 Resolution Of International Water Disputes: Papers Emanating From The Sixth P.C.A. International Law Seminar, Nov. 8, 2002 (Int'l Bureau of Permanent Court of Arbitration ed., 2003) (providing comprehensive review of issues and methods).

${ }^{41}$ Para 5 page 21 https://unctad.org/en /Publications Library/ ldcr2017_en.pdf

42 See, e.g., Rio Declaration on Environment and Development, June 1992, Principle 15, U.N.Doc.A/ CONF/151/5/Rev.1,31I.L.M.874(1992), available at http://www.unep.org/ Documents/Default.asp? Document $1 \mathrm{D}=78 \&$ ArticlelD=1163; see also Arie Trowborst, Evolution And Status Of The Precautionary Principle In International Law (2002); James Cameron, The Precautionary Principle in International Law, in Reinterpreting The Precautionary Principle 113 (Tim O' Riordan, James Cameron \& Andrew Jordan, eds, 2001); Charles Weiss, Scientific Uncertainty and Science Based Precaution, International Environmental Agreements: Politics, Law And Economics 137-66 (2003).

43 Member Countries, OPEC, available at http://www. opec.org. A significant difference between OPEC and non-OPEC countries is that OPEC countries produce most of their oil for export.

44 Member Countries, WTO, available at http://www.wto. org.

45 In the transportation sector, however, there is still no economically viable substitute for oil available on a large scale.

46 Cecilia Tortajada \& Kimberly Pobre The SingaporeMalaysia water relationship: an analysis of the media perspectives, (2011) 56(4) Hydrological Sciences Journal, p.p597-614, DOI: 10.1080/02626667.2011.579074

47 See John H. Jackson et al., Legal Problems Of International Economic Relations 242-4 (4th edn, 2002).

48 Resolution Of International Water Disputes: Papers Emanating From The Sixth P.C.A. International Law Seminar, Nov. 8, 2002 (Int'l Bureau of Permanent Court of Arbitration ed., 2003) (providing comprehensive review of issues and methods).

49 Para 5 page 21 https://unctad.org/en/Pu blications Library/ ldcr2017 en.pdf

50 See, e.g., Rio Declaration on Environment and Development, June 1992, Principle 15, U.N.Doc.A/ CONF/151/5/Rev.1,31I.L.M.874(1992), available at http://www.unep.org/Documents/Default.asp? Document $1 \mathrm{D}=78 \&$ ArticlelD $=1163$; see also Arie Trowborst, Evolution And Status Of The Precautionary Principle In International Law (2002); James Cameron, The Precautionary Principle in International Law, in Reinterpreting The Precautionary Principle 113 (Tim O' Riordan, James Cameron \& Andrew Jordan, eds, 2001); Charles Weiss, Scientific Uncertainty and Science Based Precaution, International Environ-mental Agreements: Politics, Law And Economics 137-66 (2003).

51 Member Countries, OPEC, available at http://www. opec.org. A significant difference between OPEC and non-OPEC countries is that OPEC countries produce most of their oil for export.

52 Member Countries, WTO, available at http://www.wto.org.

53 In the transportation sector, however, there is still no economically viable substitute for oil available on a large scale.

54 Cecilia Tortajada \& Kimberly Pobre The SingaporeMalaysia water relationship: an analysis of the media perspectives, (2011) 56(4) Hydrological Sciences Journal, p.p597-614, DOI: 10.1080/02626667.2011.579074

\section{REFERENCES}

Salman M. A. Salman \& Siobhan Mclnerney. 2004. Lankford, The Human Right To Water.

General Agreement on Tariffs and Trade, April 15, 1994, 1867 U.N.T.S. 3, available at http:// www. wto.org/english/docs_e/legal_e/ursum_e. htm\#General [herein $\neg$ after GATT 1994].

North American Free Trade Agreement, December 17, 1992, U.S.-Can.-Mex, available at http://www.naftasec-alena.org/DefaultSite/index e.aspx [hereinafter NAFTA].

Intergovernmental Panel on Climate Change (IPCC), Third Assessment Report, Climate Change 2001: Impacts, Adaptation and Vulnerability Ch. 4.3.2 Precipitation (2001), available at http://www.grida. no/climate/ipcc_tar/wg2/index.htm

S. Hodgson. 2004. Land And Water-The Rights Interface, See Chapter 6, Food And Agriculture Organization Of The United Nations Rome, Fao Legislative Study 84.

Canadian Government: Strategy [to] Prohibit the Bulk Removal of Canadian Water, Including Water for 
Export, M2PRESSWIRE, February 2, 1999, available at 1999 WL 12604553. Removal for bottling would not qualify.

Quebec Water Resources Preservation Act, R.S.Q. P-18.1, sec. 2, para. 1, 1999, available at http://www. canlii.org/qc/laws/sta/p-18.1/20041104/whole.htm.

Robert J. Girouard, 2003. Water Export Restrictions: A Case Study of WTO Dispute Settlement Strategies and Outcomes, GEO. INT'L L. REV 247 (15).

NAFTA, supra note 5, Art. 201, available at http://www. nafta-sec-alena.org/DefaultSite/index_e.aspx.

World Customs Organization, Harmonized Commodity Description And Coding System: Explanatory Notes (3rd edn. 2002).

James M. Utterbach, 1994. Mastering The Dynamics Of Innovation 146-157.

Bulk Water Removals and International Trade Considerations: Document from the Canadian Department of Foreign Affairs and International Trade, Nov. 16, 1999, International Joint Commission, Protection of The Waters Of The Great Lakes: Final Report To The Gov $\neg$ ernments Of Canada And The United States, February 22, 2000, p. 67, available at http:// www.ijc.org/php/ public ations/html/finalreport.html

World Trade Organization, Committee on Technical Barriers to Trade, Notification, Doc. G/ TBT/N/Mex/8 (October 3, 2001).

Oxford Compact English Dictionary, 2013, available at http://www.askoxford.com/dictionaries/compact oed/.

Statement by the Governments of Canada, Mexico, and the, United States, 1993, available at http://www. scics.gc.ca/cinfo99/83067000_e.html\#statement.

Letter from the Deputy United States Trade Representative, November 24, 1999, International Joint Commission, Protection of the Waters of the Great Lakes: Final Report to the Governments of Canada and the United States, February 22, 2000, p. 65, available at http://www.ijc.org/php/publications/ html/finalreport.html.

Bulk Water Removals and International Trade Considerations: Document from the Canadian Department of Foreign Affairs and International Trade, Nov. 16, 1999, International Joint Commission, Protection of the Waters of the Great Lakes: Final Report to the Governments of Canada and the United States, February 22, 2000, p. 67, available at http://www.ijc.org/php/publications/html/ finalreport.html.

International Joint Commission, Protection Of The Waters Of The Great Lakes: Final Report To The Governments Of Canada And The United States, February 22, 2000, Section 8, Law \& Policy, International Legal Context, available at http://ww.ijc. org/php/publications/html finalreport.html.

World Trade Organization Appellate Body: Report of the Appellate Body in the United States-Standards for Reformulated and Conventional Gasoline (adopted 20th May, 1996), W.T.O. Doc. WT/DSZ/ $\mathrm{AB} / \mathrm{R}$.

Sporhase v. Nebraska, 458 U.S. 941 (1982).

Sanford Gaines, 2001. The WTO's Reading of the GATT Article XX Chapeau: A Disguised Restriction on Environmental Measures, U. PA. J. Int'l Econ. Law 22739.

Treaty on the Lesotho Highlands Water Project, October 24, 1986, Lesotho-S. Afr., cited in Fred. O. Boadu, 1998. Relational Characteristics of Transboundary water Treaties: Lesotho's water Transfer Treaty with the Republic of South Africa, NAT. RESOURCES J. 381() .

Salman, Legal Regime for Use and Protection of International Watercourses in the Southern African Region: Evolution and Context, 41 NAT. RESOURCES J. 981 et seq. http://web.worldbank. org/WBSITE/EXTERNAL/NEWS/0contentMDK:20 018028 menuPK:34460 pagePK:64003015 piPK:6 4003012 theSitePK:4607,00.html.

Vienna Convention on the Law of Treaties, May 22, 1969, 1155 U.N.T.S. 331.

Joshua Brilliant, 2002 'Israel to Import Water from Turkey', United Press International, March 20.

William M. Turner, 2004 'Water Export from Manavgat, Turkey', April 1, at http://www.waterbank. com/Newsletters/nws23.htm1.

Turkey Plans Water Export to Gulf States', March 29, 2004, at http://www.turks.u s.article

'Iran Says It Will Export Water to Kuwait: Daily', July 31, 2000, at http://www.pavvand.com/news/00/jul/11 34.html

Brian D. Anderson, 1999. Selling Great Lakes Water to a Thirsty World: Legal, Policy \& Trade Considerations, BUFF. ENVT'L. L. J. 6: 245.

William M. Turner, 'Bolivia Permits Bulk Export of Water to Chile', at http://www.waterbank.com/ Newsletters/nws39.html.

http://www.circleofblue.org/waternews/2013/world/ alaska-legislative-committee-to-discuss-bulk-waterexports/

Sun Belt Water, 1998Inc. v. Gov't of Canada, November 27, available at http://www.dfait-maeci. gc.ca/tna-nac/disp/sunbelt_archive-en.asp.

Environment Canada, Water Policy and Legislation: Jurisdictional Responsibilities, at http://www.ec. gc.ca /water/en/policy/coop/e-juris.htm.

Canadian Federal Water Policy, available at http://www. ec.gc.ca/water/en/info/pub s/ fedpol/e_fedpol.htm

An Act to Amend the International Boundary Waters, Treaty, December 18, 2001, 2001. S.C. ch. 40, available at http://www.canlii.org/ca/as/2001/c40/ sec1.html.

John H. Jackson et al., Legal Problems Of International Economic Relations 2424 (4th edn, 2002).

Resolution Of International Water Disputes: Papers Emanating From The Sixth P.C.A. International Law 
Seminar, Nov. 8, 2002 (Int'l Bureau of Permanent Court of Arbitration ed., 2003.

Rio Declaration on Environment and Development, June 1992, Principle 15, U.N.Doc.A/CONF/151/5/ Rev.1,31I.L.M.874(1992), available at http:// www.unep.org/Documents / Default.asp? DocumentlD $=78 \&$ ArticlelD $=1163$;

Sarie Trowborst, 2002. Evolution And Status Of The Precautionary Principle In International Law.

James Cameron. 2001. The Precautionary Principle in International Law, in Reinterpreting The 2003P. Precautionary Principle 113 (Tim O' Riordan, James Cameron \& Andrew Jordan, eds, 2001); Charles Weiss, Scientific Uncertainty and Science Based Precaution, International Environmental Agreements: Politics, Law And Economics 137-66.

Member Countries, WTO, available at http://www. wto.org.

Cecilia Tortajada \& Kimberly Pobre. 2011. The Singapore-Malaysia water relationship: an analysis of the media perspectives,) Hydrological Sciences Journal 56(4), p.p597-614, DOI: 10.1080/02626667.2011.579074

Rozlinda Mohamed Fadzil

Faculty of Law

Universiti Kebangsaan Malaysia

43600 Bangi, Selangor

Emel: leenda@ukm.edu.my

Haniff Ahamat

Faculty of Law

Universiti Kebangsaan Malaysia

43600 Bangi, Selangor

Emel: haniff@ukm.edu.my

Rasyikah Md. Khalid

Faculty of Law

Universiti Kebangsaan Malaysia

43600 Bangi, Selangor

Emel: rasyikah@ukm.edu.my 